\title{
BRUNEI DARUSSALAM Consolidating the Foundations of its Future?
}

\section{Christopher Roberts}

Political stability in Brunei Darussalam - the abode of peace - is built on oil wealth and Brunei's citizens subsequently enjoy some of the best standards of living in Asia. This fortuitous state of affairs is reinforced by a small population of just 402,000 - two thirds of whom are ethnic Malays. Nonetheless, a range of short, medium, and long-term challenges have compelled the kingdom to be increasingly innovative and, in some areas, more progressive for the purpose of maintaining long-term economic and social stability. Such themes are evident in the three sections covered by this chapter. The first section focuses on Brunei's economy. While the economy has not been particularly strong in recent years, the section reveals that some developments have either taken place, or are in the process of being implemented, that may eventually strengthen the foundations for a more robust economy. The second section examines the political environment of Brunei and finds that while there has been little change to the institutions of government, there were a number of subtle policy reorientations for the purpose of responding to past omissions and new problems. The final section examines the country's foreign relations and developments concerning its defence policy. Here, significant events included Brunei's relations with China together with a final resolution of Brunei's maritime disputes with Malaysia. Overall, 2010 was a crisis free year that enabled the Kingdom of Brunei to refine some of its political and economic policies.

Christopher Roberts is Senior Lecturer in International Relations and Asian Studies, National Security College, Australian National University. 


\section{The Economy: Strengthening the Foundations for Diversification?}

By the close of 2010, the GDP (purchasing power parity) per capita for the Kingdom of Brunei was US\$50,300 - the second highest in Southeast Asia. The citizens of Brunei also enjoy some of the best social welfare and healthcare in Asia and the average life expectancy also sits at a very high 77.4 years of age. Further, Brunei maintains the highest global rating for macroeconomic stability and the nation is also ranked first in the Islamic world on the United Nations Human Development Index. ${ }^{1}$ Brunei owes this prosperity to the profits that stem from 1.1 billion barrels of oil reserves (2009 estimate) and 400 billion cubic metres in natural gas reserves (2010 estimate). However, Brunei's economy is not without challenges. While the economy grew by an estimated 0.5 per cent in 2010 , the change in real GDP was -0.5 per cent in 2009 and -1.9 per cent in 2008. Further, Brunei's economic performance is well below the rest of Southeast Asia where the ASEAN economies expanded by an average of 7.4 per cent in $2010 .^{2}$ Ironically, Brunei's recent economic performance is a consequence of its continued reliance on fossil fuels where, in 2009, the country's hydrocarbon revenues declined by BN\$4,591.8 million (37.4 per cent) compared to 2008. While a 38 per cent decline in global crude oil prices contributed to this outcome, the government's policy to cap production levels also had some bearing. ${ }^{3}$ At its peak, oil production had reached 240,000 barrels per day (bpd) in 1979, but by 2008 production had been reduced to $138,070 \mathrm{bpd}$, and then down to $132,140 \mathrm{bpd}$ in 2009 . This policy has been deemed necessary in order to extend the life cycle of the remaining reserves, which are currently estimated to expire within twenty-five years. ${ }^{4}$

Under the leadership of the Sultan, His Majesty Haji Hassanal Bolkiah, the government has sought to respond to the country's economic challenges through the formation of new industries, an expansion of agricultural production, and the utilization of other natural resources - e.g., bio-prospecting. In the process, the government is also seeking to generate new opportunities for employment as the government sector - currently the largest single source of employment - is now saturated to the stage where many new appointments are relatively unnecessary and dispiriting. The manner by which the sultanate has sought to diversify the economy has also been guided by Islamic philosophy and the traditions of tolerance, compassion, and social harmony as incorporated in the Wawasan (vision) Brunei $2035 .{ }^{5}$ In order to realise this vision, His Majesty has calculated that the economy will need to grow by an average of 6 per cent per year. ${ }^{6}$ While a 2009 increase of BN\$81.6 million in non-oil and gas exports represented a small step in the right direction, for the immediate future the government's economic goals will remain 
unfeasible because, as recently as 2009, oil and gas exports represented 96.1 per cent of total exports. ${ }^{7}$ Further, GDP growth has averaged just 0.54 per cent since 2006. Nonetheless, the Sultan has called on his ministries to forge ahead with new plans to assist with the development of the nation. Meanwhile, His Majesty has also likely calculated that a degree of financial pressure - as generated by a continued cap on oil and gas outputs - may further motivate progress in the development and diversification of Brunei's economy.

Problematically, the environment for starting new businesses and industries has not been particularly good despite various titahs (royal speeches or decrees) underlining the need to address this problem. For example, back in 2009 the Sultan reprimanded his ministers and officials for their "failure to be proactive in a number of areas that required appropriate action plans" and added "his abhorrence of the practice of acting like robots". ${ }^{8}$ The Sultan subsequently repeated this theme in February 2010 when he criticised the continuation of poor performance, adding that "we want to see what has been planned is completed according to its deadline and not simply remain as plans on paper". ${ }^{9}$ Despite the Sultan's encouragement, the CEO of the government's Brunei Economic Development Board (BEDB), Vincent Cheong, argues that Brunei's "small population makes it hard to build economies of scale for major industries". He adds that meanwhile, "Brunei's entire government relies heavily on the say-so of one man: the Sultan. Disappoint him, and it's likely to be the end of your political career. That has led to a strong dose of conservatism in the country when it comes to thinking outside the box." 10 While these concerns were reinforced by the "2011 Doing Business" report, which ranked Brunei 112 out of 183 countries for the "ease of doing business", the report also revealed some limited progress as Brunei was ranked five places higher than the year before. ${ }^{11}$ Further, the government announced in April that it will be reducing the corporate tax rate from 23.5 per cent to 22 per cent, thereby providing some improvement to the financial climate for businesses. ${ }^{12}$ Nonetheless, despite many plans and initiatives for the development of domestic industries - such as information technology, Halal-branded food exports, tourism, and renewable energy, including bio-prospecting ${ }^{13}$ - the earlier GDP figures indicate the progress in these sectors is yet to contribute to strong economic growth.

Brunei's policy of diversification includes greater self-sufficiency through a reduced dependence on imported goods, such as rice. Consequently, in 2008, the Sultan delivered a titah where he declared that the country needed to increase rice production from 3.2 per cent of consumption to 20 per cent by 2010 and 60 per cent by 2015. In the pursuit of these goals the kingdom has experimented with hybrid rice technologies. While non-hybrid rice plantations (e.g., Laila rice) 
typically average only 2-3 tons of rice per hectare, a September 2010 trial of a new hybrid rice variety yielded 11-13 tons per hectare. However, in the absence of import restrictions, these new rice cultivation technologies may also need to overcome the more subjective obstacle of "acceptance" by the Bruneians, who are noted for being "very particular in regards to taste". ${ }^{14}$ Meanwhile, the Brunei Government has sought other methods to increase annual rice yields and exports, including double cropping (with the potential to increase non-hybrid rice yields to 4 tons per hectare), increased allocations of land for rice cultivation, and increased international cooperation with countries such as Thailand and Singapore. ${ }^{15}$ Despite these initiatives, at the time of writing the government had not released any data on the level of rice production for 2010, and this omission, combined with certain government statements (e.g., that it was more focused on the Brunei Halal Brand initiative), suggest that the size of the 2010 harvest may have fallen short of the kingdom's goal.

Meanwhile, a relatively important development for Brunei's economy concerned the May 2010 completion of a US\$450 million methanol plant in the new Sungai Liang Industrial Park. However, the pace of construction was very slow (six years from inception to completion) and the broader park itself - which opened in the second quarter of 2010 and is intended to provide a special zone for petrochemical investments - remains inadequate for the purpose of "foreign investors who require infrastructure, human resources, and a free and comfortable environment". ${ }^{16}$ Further, while Brunei has not published any statistics concerning FDI (foreign direct investment) inflows since 2008, the government's track record in earlier years was not particularly encouraging. For example, between 2006 and 2008 FDI inflows nearly halved from US\$434 million to US\$239 million. ${ }^{17}$ Nonetheless, the operation of the methanol plant, together with construction work concerning a new power line between Malaysia and Brunei and the new Pulau Muara Besar Port, have contributed to a forecast GDP growth of 1.3 per cent in 2011-12. ${ }^{18}$ Brunei is also likely to continue to benefit from the commencement of the China-ASEAN Free Trade Area (CAFTA). Following the inauguration of CAFTA in January 2010, trade between China and Brunei reached US\$822 million during the first ten months - more than double the same period the year before. Should these trends continue in 2011 then China may usurp Singapore and South Korea to become Brunei's third-largest trading partner after Japan and Indonesia.

In 2010, Brunei also completed an amendment to its income tax legislation in line with the Organisation for Economic Cooperation and Development (OECD) standards, including an effective legal infrastructure for the exchange of 
information and greater transparency. These legal amendments will also increase the government's capacity to track tax evaders. ${ }^{19}$ Significantly, the Sultan announced in July that he will be establishing a new apex financial institution called the Monetary Authority of Brunei Darussalam. The institute will be responsible for the nation's monetary policy, the monitoring of other financial institutions, and currency trading. ${ }^{20}$ Meanwhile, a key pillar behind the macroeconomic stability of Brunei concerns a fixed exchange rate system where the Brunei dollar is fixed to the Singapore dollar at parity, and this has also served to protect Brunei from inflationary pressures. ${ }^{21}$ Meanwhile, and despite attempts to diversify the economy, the oil and gas sectors will continue to provide a very lucrative safety net for the foreseeable future. Further, this safety-net was strengthened when Total, a French oil company, revealed in October 2010 that it had found a substantial new gas field which it expected to bring into production within three years. ${ }^{22}$ Moreover, the Economist Intelligence Unit predicts that additional discoveries of oil and/or gas are likely to occur between 2011 and 2012.

\section{Domestic Affairs: Balancing between Conservatism and Reform}

As noted earlier, the Sultan has been critical of his government's lack of initiative and the poor pace of reform. Such criticism also extends to the political arena and, in contrast to the earlier mentioned views by Vincent Cheong, the Sultan directed the members of his Legislative Council (LegCo) to "express their views without fear, doubt or hesitancy, especially on matters relating to the country and the people's welfare". ${ }^{23}$ LegCo was convened for the first time in twenty years on 24 September 2005. It currently has twenty-six members as three members have recently passed away. ${ }^{24}$ While the majority of the LegCo members are directly appointed by the Sultan, five delegates are indirectly elected as representatives for the village councils. During the first session, the Sultan announced an intention for partial democratization through the election of new representatives that will expand LegCo's membership to forty-five. However, the current appointees would remain and, moreover, such plans appear to have been indefinitely delayed. Nonetheless, Jane's Intelligence contends that a cabinet reshuffle in May 2010 has been interpreted as an attempt to replace conservative ministers with a "more corporate and technically experienced team". ${ }^{25}$ Given this, together with the Sultan's directives, recent legislative debates, and the appointment of the country's first female minister in May 2010, the country may have taken a few tentative steps towards a more liberal society. ${ }^{26}$ 
While the political environment may have opened marginally, the government has remained vigilant in the prevention of any dissent. For instance, through the Societies Order two political parties were banned between 2007 and 2008 and the only remaining political party is the National Development Party (NDP; Parti Pembangunan). However, the NDP only has a few hundred members and plays no significant role in Bruneian society. ${ }^{27}$ Meanwhile, on 6 July 2010 the Royal Brunei Police Force, in cooperation with the Authority for Info-Communications Technology (AiTi), conducted a roadblock to enforce laws prohibiting the use of radio communication or other telecommunication systems in the absence of an appropriate licence. When a journalist from the Borneo Bulletin asked how many offenders were caught, an officer from the AiTi responded that "a lot" had been caught but would not reveal the precise number. A conviction for the offence can result in a fine of $\mathrm{B} \$ 10,000$ and/or up to three-years' imprisonment. Nonetheless, the human rights environment in Brunei remains relatively benign. For example, the last political prisoner held under the Internal Security Act (a vestige from British colonialism) was released in January 2009. ${ }^{28}$ While the 2009 annual Human Rights Report by the U.S. Department of State highlights some problems - such as "limited freedom of speech, press, assembly, and association", "religion", and "discrimination against women", ${ }^{29}$ - marginal improvements to women's rights have occurred in recent years. For example, the government has made a number of high profile female appointments, including the aforementioned appointment of a female minister, and the government had earlier (April 2009) abolished a policy that had forced female civil servants to resign upon marriage. ${ }^{30}$ During a titah in October 2010, the Sultan also called on his government to consider extending maternity leave from 56 days to 100 days. ${ }^{31}$

A further issue of concern involves Brunei's ethnic Chinese, who comprise about 15 per cent of the populace. However, as many as 90 per cent of the ethnic Chinese have not been granted citizenship and have therefore been denied the full rights and benefits of their Malay counterparts. ${ }^{32}$ Nonetheless, recent events - including the appointment of an ethnic Chinese minister in 2005 - indicate an intention to better integrate the Chinese into Bruneian society. Brunei's strengthened relationship with China - as discussed further below - will provide added pressure for the government to improve the plight of the resident Chinese. Interestingly, shortly after the close of 2010, the Ministry of Home Affairs announced that it had embarked on accelerating "the citizenship process to Permanent Residents, especially for the "stateless". ${ }^{33}$ Meanwhile, large components of the immigrant workforce are from the Philippines and foreign labour represents 30-40 per cent of the total workforce. Significantly, both the Filipinos and Chinese are generally 
free to practice their own religion but they are prohibited from proselytizing. Foreign workers, however, remain unprotected by labour laws, and breaches of their visas frequently result in imprisonment and, less frequently, being caned or whipped. ${ }^{34}$ In November the media reported an example of a visa breach by an Indonesian woman who had been working as a part-time maid, and while the article did not provide details of her potential punishment it was likely intended to serve as a warning to other Bruneians - some of which were making similar arrangements "via sms". ${ }^{35}$

Meanwhile, the Sultan stated that he was concerned about certain "social ills" that have been affecting both government agencies and Brunei's society more generally. Consequently, during a 16 September titah, His Majesty pointedly remarked that it was clear some government agencies had committed certain lapses in their duties and he added that "you are, without a doubt, the foundation of conduct and the stronghold of harmony". The Sultan's comments were spurred by a number of events, including the death of a subject that allegedly occurred while in police custody. ${ }^{36}$ Meanwhile, a number of trials concerning corruption had also transpired, including the conviction and six-month sentence of Brunei's former Forestry Department Director for misappropriating BN\$1,400 in government funds. ${ }^{37}$ The Sultan also expressed his concern about a recent increase in criminal behaviour, including a spate of robberies where the victims (including an unnamed "VIP") were tied up during the robbery. ${ }^{38}$ Other criminal activities include relatively limited problems in regard to human trafficking as well as drug trafficking and abuse. For example, in July 2010 an Australian court sentenced a Brunei citizen to seven years imprisonment for attempting to smuggle 470 grams of heroin into Australia from Malaysia. ${ }^{39}$ Meanwhile, Brunei's Narcotics Control Bureau arrested a Brunei citizen in January 2010 for selling syabu (methamphetamine) around Kamong Ayer in the Capital. ${ }^{40}$ In response to some of these developments, the Sultan has utilized several titahs to emphasize the need to build stronger values through the reintroduction of compulsory religious education. In June 2010, the Ministry of Religious Affairs responded with an announcement that this will occur once a draft of the new Religious Education Order has been finalized and implemented. ${ }^{41}$

\section{Foreign Affairs and Defence: Towards a New Era in Friendly Relations}

Throughout 2010 Brunei continued to make significant headway in strengthening and diversifying its multilateral and bilateral relations throughout the Asia- 
Pacific and across the globe. Accordingly, Brunei has maintained its support for ASEAN and the Sultan attended the 17th ASEAN Summit, where he met with leaders of the nine other ASEAN member states. As a very small country, ASEAN provides one of the few mechanisms where the kingdom can exercise a diplomatic voice. Consequently, Brunei maintained a steady pace of activities that included hosting the 7th ASEAN Ministerial Meeting on Social Welfare and Development (24 November); the 16th ASEAN Transport Ministers Meeting (11-12 November); the 6th Meeting of the Conference of the Parties to the ASEAN Agreement on Transboundary Haze Pollution and the 12th Informal ASEAN Ministerial Meeting on the Environment (13 October); the second meeting of the ASEAN Fisheries Consultative Forum (21 June); and the 13th ASEAN Tourism Ministers' Meeting (24-25 January). At Indonesia's request, Brunei also relinquished the ASEAN Chair to Indonesia in 2011 as the previous schedule clashed with Indonesia's hosting of the Asia-Pacific Economic Cooperation (APEC) meetings. Aside from the ASEAN Chair in 2013, Brunei is also set to host the second ASEAN Defence Ministers Meeting (ADDM) Plus the same year. ${ }^{42}$ Meanwhile, in relation to some of the more crucial issues that were addressed by ASEAN - such as whether to opt for an expanded East Asia Summit or a new ASEAN Plus Eight mechanism - Brunei maintained its usual approach of, in the words of Graeme Dobell, "sitting on the fence". ${ }^{43}$

Brunei also continued to be active in the seventeen-year-old Brunei Darussalam-Indonesia-Malaysia-Philippines-East ASEAN Growth Area (BIMPEAGA) forum by supporting a new proposal to promote the sub-region as a single tourist destination that will be branded "Equator Asia". ${ }^{44}$ ASEAN has also been seeking to expand tourism, including an agreement on the ASEAN Tourism Strategic Plan 2011-2015. Significantly, the agreement permits tourist professionals to work in any ASEAN country and tourists will also be able to travel throughout ASEAN on a single visa. ${ }^{45}$ The group also declared a commitment to synergize cooperation over what they claimed could amount to US $\$ 50$ billion in food exports every year. ${ }^{46}$ However, Brunei's contribution to such a market will remain small. Meanwhile, the Philippines Trade and Industry Secretary, Gregory L. Dominico, argues that the members of BIMP-EAGA will "need to change tack" if the grouping is to have any meaningful effect on regional development and trade as the grouping has yet to harmonize customs and immigration procedures and the coordination of port operations also remains underdeveloped. ${ }^{47}$ Brunei has also been involved in negotiations for the Trans-Pacific Partnership Agreement, a free trade agreement (FTA) involving eight countries: Brunei, Chile, New Zealand, Singapore, the United States, Australia, Peru, and Vietnam. Should the FTA be 
finalized then Brunei may gain improved market access and, in the process, avoid the inefficiencies associated with the current noodle bowl of thirty bilateral and multilateral trade agreements that these countries are currently affiliated with. ${ }^{48}$

Trade concerns were also a key issue in Brunei's bilateral relations, and various modalities for the establishment of heighted economic cooperation (in addition to political cooperation and cultural exchanges) were considered through high-level meetings with Singapore, Malaysia, Thailand, Vietnam, Australia, New Zealand, Oman, Tajikistan, Kuwait, Iran, the United States, and China. In the case of China, the aforementioned increases in trade have coincided with a notable warming of relations where a "Year of Friendship" will be celebrated between the two countries in 2011. Here there has also been a notable increase in the number of exchanges between leaders and high-ranking officials where the Sultan, for example, has visited China eight times since $1993 .{ }^{49}$ However, the most significant development involves an intended memorandum of understanding (MoU) that, according to China's Ambassador to Brunei, will provide for "general cooperation ... in the area of energy, which includes oil and gas as well as downstream and upstream of the industry". ${ }^{50}$ Details about the MoU were to be released during Premier Wen Jiabao's visit to Brunei in April 2010, but his trip was indefinitely postponed following a major earthquake in China. ${ }^{51}$ Since this time, very little information has been made publicly available. Nonetheless, while Brunei will likely seek a resolution to a territorial dispute with China over the Louisa Reef (South China Sea), ${ }^{52}$ an agreement concerning joint exploration will be the more likely outcome. Problematically, as China's vast territorial claims in the South China Sea also overlap with claims by Vietnam, Malaysia, the Philippines, and Indonesia, the proposed MoU could reduce ASEAN's solidarity and its diplomatic leverage vis-à-vis China.

Significant progress in Brunei's relations with Malaysia also occurred during 2010. Following independence from Britain, relations with Malaysia were initially hampered by territorial disputes and other sources of distrust. Then, in 2003, there was a brief naval standoff after both countries granted licences to different international oil companies to explore and extract hydrocarbon deposits from the same two blocks (L and M). However, by August 2008, a pragmatic assessment concerning the need to find new energy deposits led to a reported agreement to resolve their overlapping territorial claims along the sea and land boundaries. ${ }^{53}$ Then, on 16 March 2009, the leaders of the two countries signed "Letters of Exchange" whereby Malaysia acknowledged that Brunei was the rightful owner of Blocks L and M but Brunei also agreed to share its revenue with Malaysia. ${ }^{54}$ For Brunei, the revenue sharing arrangement was also acceptable because it can 
benefit from Malaysia's technology and capacity to extract the energy from the two blocks. Despite this major diplomatic victory, the two countries were hesitant to boast about the agreement due to concerns over potential nationalistic backlashes. Ironically, their silence actually provided fuel for certain critics, including Malaysian opposition leader Anwar Ibrahim as well as Malaysia's former Prime Minister Mahathir Mohamad. ${ }^{55}$ Nonetheless, another production-sharing agreement involving a second deep-water block was signed by the leaders of Brunei and Malaysia in December $2010 . .^{56}$

Brunei's relations with Malaysia have also improved in other areas. For example, Brunei's Foreign Minister, Prince Mohamed Bolkiah, cited improved relations with Malaysia when he announced that Brunei will be increasing its investments in neighbouring Sabah and Sarawak. Meanwhile, Malaysia has also agreed to cooperate with the construction of a new bridge that will strengthen transportation linkages between Limbang and Temburong. ${ }^{57}$ Such developments may also be interrelated with the 2009 "Exchange of Letters" which, according to Barry Wain, also indicated a possible quid pro quo arrangement where the Sultan may, in the future, relinquish his claim to the Limbang province that currently divides the two portions of Brunei. ${ }^{58}$ While Brunei's armed forces did not participate in any bilateral military exercises with Malaysia during 2010, Malaysia's Defence Minister visited the kingdom in March for two days with the aim of strengthening bilateral cooperation. Meanwhile, Brunei's military did participate in several military exercises with a range of other countries, including Singapore, the Philippines, and, notably, the United States (through the annual Cooperation Afloat Readiness and Training exercises). Brunei's diplomacy also indicated that it was particularly interested in maintaining and strengthening defence cooperation with Australia, New Zealand, Singapore, and the United Kingdom whilst also seeking a degree of diversification through improved relations with Pakistan and new diplomacy with Russia - as reflected by a series of discussions on defence trade and the opening of a Russian embassy. ${ }^{59}$ Brunei has also continued to maintain peacekeepers in the Southern Philippines (as part of the International Monitoring Team in Mindanao) and in Lebanon (as part of a Malaysian battalion). ${ }^{60}$

In the context of "defence", the government's emphasis seems to be shifting towards a focus on investments in professionalizing the armed forces as well as information and communications technology. In the case of the former, the Royal Brunei Armed Forces awarded a three-year contract to New Zealand's Massey University to provide specialist military programmes leading to postgraduate diplomas for its military personnel. ${ }^{61}$ Other tenders for professional training courses abroad were also sought during 2010. In the context of the latter, in January 2010 
Brunei awarded Northrop Grumman a contract to develop a "joint operations centre command-and-control capability". In line with the procurement priorities that were declared in the June 2007 update to the defence white paper, the centre will enable the joint networking of assets through the "acquisition of command, control, communication, computing and intelligence (C4I) systems". ${ }^{62}$ The Sultan has also announced his intention to establish a Defence Technology Centre and later signed a contract with Singapore to construct a National Modelling Simulation Centre (NMSC) that will provide simulation and modelling technologies together with integrated training solutions. ${ }^{63}$ However, these developments have been at the expense of acquiring larger weapons systems. At the turn of 2011, Brunei did acquire two eighty-metre German patrol vessels and a further two Ijhtihad class fast patrol vessels (in addition to two the year before), but Brunei's armed forces remain too ill-equipped and understaffed to provide any real deterrent value.

Given the limited capacity of Brunei's armed forces, the nation's security continues to depend on key relationships with the United Kingdom and Singapore. Since independence, the British have provided a 2,000-strong Gurkha battalion for the defence of Brunei's sovereignty. Meanwhile, the Singapore Armed Forces maintains a permanent presence of 100 personnel together with training facilities to accommodate a 600-strong infantry battalion. During 2010, these security relationships were maintained through a series of high-level meetings, including a meeting between the Sultan and Britain's Chief of Army as well as a series of meetings between Singapore's Defence Chief and several of Brunei's senior Ministry of Defence officials. ${ }^{64}$ The monarchy has also independently recruited a 2,000-strong Gurkha Reserve Unit (GRU) from ex-British Army Gurkhas. Due to historical considerations, the structure of the GRU has been modelled on the Singapore Gurkha Contingent and, therefore, operates outside of the military's chain of command. ${ }^{65}$ Meanwhile, the recent emphasis on military professionalization may help to develop the capability of the Royal Brunei Armed forces in alternative areas, including additional peacekeeping operations. Further, the continuation of professionalization programmes is likely to reinforce a professional ethos, or esprit de corps, that will further institutionalize an aversion to any involvement in political affairs.

\section{Conclusions}

During 2010, Brunei performed best internationally. Brunei has continued to maintain an active role in multilateral forums, such as ASEAN and BIMP-EAGA, and has also continued to strengthen its relations with key countries across the 
globe. One of the more notable examples concerns the warming of relations with China amidst a rapid increase in bilateral trade. However, should an MoU over energy cooperation in the South China Sea - including oil and gas - be finalized, then this may detrimentally effect other ASEAN members whose claims also conflict with China's claims to the maritime subregion. More positively, the resolution of the remaining maritime disputes with Malaysia represented a major diplomatic coup for Brunei and the region. The agreement provides oil companies with a green light to explore new areas for hydrocarbon deposits and there is now some possibility that new hydrocarbon finds will boost Brunei's depleting reserves. However, positive developments in the hydrocarbon sphere may, in turn, reduce the sense of urgency concerning economic diversification and thereby undermine the establishment of new industries and sources of employment. Here, the sultanate is already struggling with its attempts to diversify the economy due to the continuation of a poor business climate as well as the conservativeness of various government ministries in implementing reforms and other initiatives. However, the establishment of the new Monetary Authority of Brunei Darussalam, together with certain tax reforms and other developments, may eventually strengthen the foundations for investment and economic diversification.

In the political sphere, some old and new problems involving crime, corruption, and social decadence continued to affect the abode of peace. While the government has responded by reintroducing compulsory religious education, the responses thus far are likely to remain inadequate for the purpose of addressing other sources of discontent - particularly among the youth - due to a lack of career opportunities and other interests that might help direct their energies in more constructive directions. Meanwhile, recent trials and convictions concerning corruption indicate that the country is continuing to strengthen the rule of law and the level of accountability. Aside from a decision to reintroduce compulsory religious education, the country has become more open in terms of women's rights and there appears to be a gradual reorientation of policy to better incorporate the ethnic-Chinese minority as an integral part of Bruneian society. Meanwhile, the nature of the most recent cabinet reshuffles and the appointment of the first woman minister represented positive developments. However, the government's record in terms of formally liberalizing its political institutions has been less positive. The plan to partially democratize the LegCo, as announced in 2005, appears to have been deferred indefinitely as it has not been mentioned in the government's public discourse for several years. Moreover, during the course of the last four years, the level of freedom regarding political association and the right to register political parties has actually regressed. Nonetheless, Brunei Darussalam is likely to 
continue to enjoy strong economic and political stability for several more years. However, the government will need to significantly improve its performance in relation to economic management and some political issues for the purpose of ensuring continued stability throughout the decades that follow.

\section{Notes}

1 Data obtained from the CIA World Factbook, the 2010 United Nations Human Development Report, and the 2009-2010 Global Competitiveness Report.

2 Asian Development Outlook 2010: Update (Mandaluyong City, Philippines: Asian Development Bank, 2010), p. 112.

3 Ibid., p. 118.

4 “Natural Resources, Brunei”, Jane’s Sentinel Security Assessment, 10 January 2010.

5 "Wawasan Brunei 2035", Brunei Economic Development Board <www.bedb.com>.

6 Azaraimy H.H., "Brunei Must Strive for 6pc Economic Growth over the Next 25yrs", Borneo Bulletin, 23 November 2010.

7 External Trade Statistics (Bandar Seri Begawan: Department of Statistics, Prime Minister's Office, 2009), p. 1.

8 Pushpa Thambipillai, "Brunei Darussalam in 2009: Addressing Multiple Challenges", in Southeast Asian Affairs 2010, edited by Daljit Singh (Singapore: Institute of Southeast Asian Studies, 2010), p. 71.

9 Waleed P.D. Mahdini, "Clean Up the Way Government Works", Borneo Bulletin, 23 February 2010.

10 Richard Morrow, "Brunei Aims to Go Green with Oil and Gas Economy", AsiaMoney $<w w w . a s i a m o n e y . c o m>$.

11 Azaraimy, "Brunei Must Strive for 6pc Economic Growth". However, the same report ranked Brunei as one of the top ten "business reformers" and as one of the top ten "most improved in business regulation". The report is published by the International Finance Corporation (IFC) and the World Bank; Azlan Othman, "Brunei in Top 10 for Doing Biz, Reforms", Borneo Bulletin, 5 November 2010.

12 "Brunei: Tax Cut May Up Appeal of Plc-Type Set-Up", Plus News Pakistan, 10 April 2010.

13 While there has been some progress concerning the sale of Brunei's Halal-branded food locally, these products are yet to have any significant effect on the level of exports from Brunei.

14 Comments by the Deputy Permanent Secretary of the Ministry of Industry and Primary Resources (Brunei); “Hybrid Promises ‘Quantum Leap' for Brunei Rice Production”, BBC, 19 September 2010.

15 For example, the hybrid trials incorporated technology from Singapore, while the Brunei Minister for Industry and Primary Resources met with his Thai counterpart in Bangkok in March 2010 to discuss further areas of cooperation; "Thailand/Brunei: 
Thailand and Brunei Forge Closer Ties to Develop Agriculture and Halal Business", Thai News Service, 30 March 2010.

16 Samuel C.Y. Ku, "Brunei in 2009: Maturity in Doubt?" Asian Survey 50, no. 1 (2009): 6; Increased FDI will be particularly important for the purpose of realizing the Wawasan Vision 2035, and the Sultan's representatives to the BIMP-EAGA Business Council, for example, have also acknowledged that increased FDI will be unlikely to occur until Brunei improves its infrastructure, logistics, and the transport system; De No Goh, "Brunei: Better Infrastructure Needed to Attract Foreign Direct Investment to Brunei”, Plus News Pakistan, 6 April 2010.

Country Statistics Profile (Jakarta: ASEAN Secretariat, 2010).

"Country Report: Brunei”, Economist Intelligence Unit, December 2010, p. 10. "Brunei Introduces New Income Tax Law", IHS Global Insight, 20 April 2010.

"Monetary Authority for Brunei," Borneo Bulletin, 16 July 2010.

"Country Report: Brunei”, p. 11.

"New Gas, Condensate Discovery in Block B", AsiaOne <http://business.asiaone.com>; Interestingly, recent reports indicate that the newly completed methanol plant will be shut down in March 2011 for approximately one month for maintenance; "Methanol Plan Planned to be Taken Offstream by Brunei Methanol Company", Polymerupdate $<w w w . p o l y m e r u p d a t e . c o m>$.

$\mathrm{Ku}$, "Brunei in 2009: Maturity in Doubt?" p. 263.

"Brunei Darussalam Country Brief", Australian Government: Department of Foreign Affairs and Trade <www.dfat.gov>.

25 "Brunei: Internal Affairs", Jane's Sentinel Security Assessment - Southeast Asia, 10 January 2011.

26 Sit Hajar, "Brunei Names First Woman Cabinet Minister", Borneo Bulletin, 30 May 2010.

27 Christopher Roberts and Lee Poh Onn, "Brunei Darussalam: Cautious on Political Reform, Comfortable in ASEAN, Pushing for Economic Diversification", in Southeast Asian Affairs 2009, edited by Daljit Singh (Singapore: Institute of Southeast Asian Studies, 2009), pp. 63-64. "Brunei: Internal Affairs".

“2009 Human Rights Report: Brunei Darussalam”, U.S. Department of State <www. state.gov>.

30 "Freedom in the World 2010 - Brunei", Freedom House <http://www.unhcr.org/ refworld/docid/4c0ceb01c.html>.

31 "Country Report: Brunei”.

$32 \mathrm{Ku}$, "Brunei in 2009: Maturity in Doubt?" pp. 263-64.

33 Rokiah Mahmud, "294 New Brunei Citizens", Borneo Bulletin, 25 January 2011.

34 "Freedom in the World 2010 - Brunei".

35 Danial Norjidi, "Part-Time Maid Caught Working Illegally in Brunei", Borneo Bulletin, 17 November 2010. 
36 Mahdini Waleed P.D. "Wake Up Call to Country's Law Enforcement Agencies”, Borneo Bulletin, 17 September 2010.

37 "Brunei's Ex-Forestry Department Director Jailed for Corruption", Borneo Bulletin, 10 January 2010.

38 Waleed P.D. "Wake up Call".

39 Syafiq Affendy, "Brunei Drug Mule Gets 7 Years in Oz", Borneo Bulletin, 6 July 2010.

40 "A Brunei Citizen Has Been Arrested and Detained by the Narcotics Control Bureau", Plus News Pakistan, 14 January 2010.

41 Izam Said Yaa'kub, "Religious Education Compulsory for Muslim Children in Brunei”, Brunei Times, 28 December 2010.

42 David Capie and Brendan Taylor, "Two Cheers for the ADMM+", PacNet Newsletter, 21 October 2010.

43 Graeme Dobell, "Scoop: Asean's Divide on the US", Lowy Institute, The Interpreter $<$ http://www.lowyinterpreter.org $>$.

44 "The Brunei Darussalam-Indonesia-Malaysia-Philippines-East Asian Growth Area", Plus News Pakistan, 26 January 2010.

45 "ASEAN Adopts Tourism Strategic Plan" <www.philstar.com>.

46 Andi Hajramurni, "East ASEAN Set to Become "Food Basket" in Asia", Jakarta Post, 27 November 2010.

47 "RP Urges Change in Dev't Strategy for BIMP-EAGA Bloc", Manila Bulletin, 19 November 2010.

48 Eric Emerson, "Trans-Pacific Potential, and Pitfalls", Wall Street Journal, 29 November 2010.

49 James Kon, "Brunei-China Trade at Record Level”, BBC, 10 January 2011.

50 James Kon, "Brunei, China to Sign Health, Energy Deals During Premier's Visit", Borneo Bulletin, 15 April 2010.

51 Emma Graham-Harrison, "Premier Wen Jiabao Postpones Planned Southeast Asia Trip", Reuters, 15 April 2010.

52 Ian Storey, "China's Thirst for Energy Fuels Improved Relations with Brunei”, China Brief 5, no. 24 (2010).

53 Roberts and Lee, "Brunei Darussalam: Cautious on Political Reform”, pp. 70-71.

54 "Anifah: Brunei Will Share Revenue from Disputed Oil Blocks", Bernama, 8 June 2010.

55 Barry Wain, “KL-Brunei Deal: Silence Wasn’t Golden”, Straits Times, 10 June 2010.

56 Tom Grieder, "Malaysia and Brunei Sign Second Deepwater Block Deal Following Resolution of Territorial Disputes", IHS Global Insight, 14 December 2010.

57 Zukiman Ahmad Zain, "Brunei Sets Investment Sights on Malaysian Economic Corridors", Bernama, 21 December 2010; "Malaysia Willing to Cooperate with Brunei on Bridge at Pandaruan", Organisation of Asia-Pacific News Agencies, 24 December 2010. 
58 As Barry Wain states, "The clue to Limbang's resolution is contained in the statement's oblique reference to agreement on 'the modalities for the final demarcation of the land boundary" 'between Malaysia and Brunei; Wain, "KL-Brunei Deal: Silence Wasn't Golden”.

59 Farah Ahmandnawi, "Russia to Open Embassy Office in Brunei Hotel", Borneo Bulletin, 6 July 2010; Jon Grevatt, "Russia Looks to Break Western Monopoly in Brunei”, Jane's Defence Weekly, 11 May 2010.

60 "Brunei Joins Malaysia as Peacekeepers", New Straits Times, 30 April 2010.

61 "Defence Studies Contract with Brunei Army Secured", Scoop, 19 July 2010.

62 Grevatt, "Russia Looks to Break Western Monopoly".

63 Rokiah Mahmud, "Brunei Signs Contract to Establish Defence Modelling Simulation Centre", Borneo Bulletin, 22 January 2011.

64 "Brunei Ruler Receives British Army Chief", Borneo Bulletin, 5 February 2010; "Singapore's Defence Chief Arrives in Brunei", Singapore Goverment News, 7 October 2010.

65 Discussions with Tim Huxley, International Institute for Strategic Studies, Singapore, 26 January 2011. 
Reproduced with permission of the copyright owner. Further reproduction prohibited without permission. 